\title{
Hubungan antara tingkat pengetahuan karies gigi dengan indeks DMF-T pada siswa kelas V SD Negeri Walitelon Utara Temanggung
}

\author{
Siti Nur Hasanah a, I*, Ta'adi a, 2, Furaida Khasanah a,3 \\ a Program Studi Sarjana Terapan Terapi Gigi, Poltekkes Kemenkes Yogyakarta \\ Jl. Kyai Mojo No. 56 Pingit, Yogyakarta, 55243 \\ ${ }^{1}$ sitinurhs31@gmail.com * \\ *korespondensi penulis
}

\begin{tabular}{ll}
\hline Informasi artikel & AB \\
\hline Sejarah artikel: & \\
Diterima & \\
Revisi & \\
Dipublikasikan & \\
\hline
\end{tabular}

\section{ABSTRAK}

Usia 5-12 tahun merupakan kelompok usia yang rentan terhadap karies. Tingkat prevalensi karies yang tinggi sebesar 42,6\%

Kata kunci:

Pengetahuan

Karies gigi

Indeks DMF-T

Key word:

Knowledge

Dental Caries

DMF-T Index mecerminkan tingkat pengetahuan tentang kesehatan gigi yang rendah. Pengetahuan tentang kesehatan gigi dan mulut secara tidak langsung akan mempengaruhi kesehatan gigi dan mulut sehingga dapat mencegah karies gigi, pengetahuan digunakan sebagai suatu edukasi diri untuk mencapai kesehatan gigi dan mulut yang optimal. Mengetahui hubungan antara tingkat pengetahuan karies gigi dengan Indeks DMF-T. Jenis penelitian yang digunakan dalam penelitian ini yaitu survey analitik dengan pengambilan data cross sectional. Penelitian ini dilaksanakan pada bulan Desember-Januari 2019. Populasi dalam penelitian adalah siswa kelas V SD Negeri Walitelon Utara. Sampel penelitian ini adalah siswa kelas $\mathrm{V}$ yang berjumlah 39 anak dengan total sampling. Instrumen penelitian adalah kuesioner dan format pemeriksaan Indeks DMF-T. Data dianalisis menggunakan uji korelasi Kendall's tau-b. Tingkat pengetahuan dengan kriteria baik memiliki Indeks DMF-T rendah sebanyak 92,3\% sedang sebanyak 2,6\%, tingkat pengetahuan cukup memiliki Indeks DMF-T rendah sebanyak 5,1\%. Hasil uji Kendall's tau-b menunjukkan adanya hubungan antara tingkat pengetahuan karies gigi dengan Indeks DMF-T diperoleh nilai $\mathrm{p}=0,000(\mathrm{p}<0,05)$. Tingginya tingkat pengetahuan karies gigi mempengaruhi hasil indeks DMF-T.

\section{ABSTRACT}

The relationship between the dental caries knowledge levelwith the DMF-T index on $5^{\text {th }}$ grade students of SD Negeri Walitelon Utara, Temanggung. Ages 5 to 12 years are the age group that is susceptible to caries. The high caries prevalence rate of $42.6 \%$ reflects the low level of knowledge about dental health. The knowledge about dental and oral health will indirectly influence the health of the teeth and mouth so that it can prevent dental caries. The knowledge is used as a selfeducation to achieve the optimal dental and oral health. To find out the relationship between the dental caries knowledge level with the DMF-T Index. This research used the analytic survey with the cross-sectional data collection. This research was conducted in December 2018 to January 2019. The population in this research was the $5^{\text {th }}$ grade students of the North Walitelon State Elementary School. The samples of 
this research were the $395^{\text {th }}$-grade students with the total sampling. The research instruments were questionnaire and the DMF-T Index examination format. The data were analyzed using the Kendall's tau-b correlation test. The level of knowledge with the good criteria had a low DMF-T Index of $92.3 \%$, the moderate was as much as $2.6 \%$, and the fair knowledge level had a low DMF-T Index of $5.1 \%$. The Kendall's tau-b test results showed a relationship between the dental caries knowledge level and the DMF-T Index, and the obtained $\mathrm{p}$ value $=0,000(\mathrm{p}<0.05)$. The high knowledge level of dental caries affected the results of the DMF-T index.

This is an openaccess article under the CC-BY-SAlicense.

\section{Pendahuluan}

Pengetahuan kesehatan gigi dan mulut adalah kemampuan seseorang untuk mengetahui segala sesuatu tentang kesehatan gigi dan mulut, pengetahuan digunakan sebagai suatu edukasi diri untuk mencapai kesehatan gigi dan mulut yang optimal. Pengetahuan tentang kesehatan gigi dan mulut secara tidak langsung mempengaruhi kesehatan gigi dan mulut sehingga dapat mencegah karies gigi. ${ }^{1}$

Karies merupakan penyakit pada jaringan keras gigi, proses terjadinya karies gigi dimulai dengan adanya plak pada permukaan gigi, sukrosa dari sisa makanan, dan salah satu hasil metabolisme bakteri yaitu asam laktat kemudian menyebabkan demineralisasi sehingga menjadi karies. Jika tidak ditangani, peyakit ini dapat menyebabkan nyeri, dan jika dibiarkan tanpa disertai perawatan dalam kurun waktu tertentu akan bertambah parah. ${ }^{2}$

Berdasarkan data World Health Organization (WHO) tahun 2013, ditemukan bahwa 60$90 \%$ anak-anak sekolah dan hampir $100 \%$ orang dewasa mengalami karies gigi. ${ }^{2}$ Berdasarkan data RISKESDAS tahun 2013, tingginya prevalensi karies anak dibawah usia 12 tahun (42,6\%) yang mengalami peningkatan sebesar 13,7\% dibandingkan tahun 2007 (28,9\%) membuktikan bakwa tidak terawatnya kondisi gigi anak usia sekolah di Indonesia. Tingkat prevalensi karies yang tinggi tersebut mecerminkan tingkat pengetahuan tentang kesehatan gigi yang rendah. ${ }^{3}$

Indikator yang paling sering digunakan untuk mengetahui tingkat karies gigi adalah indeks DMF-T merupakan penjumlahan dari banyaknya kerusakan gigi permanen yang pernah dialami seseorang baik berupa Decay / D (gigi karies atau gigi berlubang), Missing / M (gigi dicabut karena karies), Filling / F (gigi ditumpat karena karies). ${ }^{4}$

Ada tiga faktor yang menjadi peran penting dalam karies yaitu faktor host atau tuan rumah, mikroorganisme atau agen, substrat atau diet. Jika tidak ada interaksi antara tiga faktor tersebut, maka karies gigi tidak akan terjadi. Kondisi setiap faktor tersebut harus saling mendukung yaitu host yang rentan, mikroorganisme, substrat yang sesuai dan waktu yang lama. ${ }^{5}$

Tujuan dari penelitian ini adalah diketahuinya hubungan antara tingkat pengetahuan karies gigi dengan Indeks DMF-T pada siswa kelas V SD Negeri Walitelon Utara, Temanggung. Tujuan Khusus penelitian ini adalah diketahuinya tingkat pengetahuan tentang karies gigi pada siswa kelas V SD Negeri Walitelon Utara, Temanggung dan diketahuinya Indeks DMF-T pada siswa kelas V SD Negeri Walitelon Utara, Temanggung.

Manfaat penelitian ini adalah : 1) Bagi Institusi Poltekkes Yogyakarta Jurusan Keperawatan Gigi yaitu menambah referensi bacaan di perpustakaan Poltekkes Kemenkes Yogyakarta Jurusan Keperawatan Gigi. 2) Bagi Penulis yaitu menambah wawasan dan 
pengetahuan bagi penulis dibidang kesehatan gigi dan mulut khususnya pengetahuan tentang karies gigi dan Indeks DMF-T. 3) Bagi Pembaca yaitu sebagai bahan kajian kepustakaan guna menambah wawasan keilmuan dan pengetahuan. 4) Bagi Pihak Sekolah yaitu mendapatkan informasi tentang Indeks DMF-T siswa dan dapat dijadikan dasar untuk program UKGS. Penelitian ini telah disetujui oleh Komisi Etik Penelitian Kesehatan Politeknik Kesehatan Kementrian Kesehatan Yogyakarta No. LB.01.01/KE-01/III/52/2019.

\section{Bahan dan Metode Penelitian}

Penelitian ini menggunakan pendekatan Survey Analitik dengan pengambilan data Cross Sectional. ${ }^{6}$ Variabel bebas pada penelitian ini adalah tingkat pengetahuan karies gigi. Variabel terikat pada penelitian ini adalah Indeks DMF-T. Populasi dalam penelitian ini adalah siswa kelas V SD Negeri Walitelon Utara, berjumlah 39 siswa dengan teknik pengambilan sampel menggunakan Total Sampling. ${ }^{7}$ Tempat penelitian ini dilakukan di SD Negeri Walitelon Utara, Temanggung, Jawa Tengah dan dilaksanakan pada bulan Desember 2018-Januari 2019. Definisi Operasional Penelitian ini yaitu tingkat pengetahuan tentang karies gigi dan Indeks DMF-T. Pengukuran tingkat pengetahuan yaitu dengan memberikan kuesioner favourable dan unfavourable. Kuesioner ini terdiri dari 15 pernyataan, dengan nilai terendah 0 dan nilai tertinggi 15. Pernyataan favourable dengan jawaban benar skor 1 dan jawaban salah skor 0, pernyataan unfavourable dengan jawaban benar skor 0 dan jawaban salah skor 1. Kriteria "Baik" apabila skor jawaban antara (11-15), "Cukup" apabila skor jawaban antara (6-10), dan "Kurang" apabila skor jawaban (0-5). Pengukuran menggunakan skala ordinal. Untuk mengetahui tingkat karies gigi menggunakan Indeks DMF-T dengan kategori rendah jika nilai DMF-T sebesar 0,0 - 2,6, kategori sedang jika nilai DMF-T sebesar 2,7 - 4,4, dan kategori tinggi jika nilai DMF-T >4,4. Pengukuran menggunakan skala ordinal. Instrumen yang digunakan pada penelitian ini berupa kuesioner pengetahuan tentang karies dan format pemeriksaan Indeks DMF-T. Analisis data menggunakan uji korelasi Kendall's tau- $b$ yaitu analisis untuk mengetahui hubungan antara dua variabel dengan data berskala ordinal. ${ }^{8}$

\section{Hasil dan Pembahasan}

Tabel 1. Distribusi frekuensi responden berdasarkan jenis kelamin

\begin{tabular}{ccc}
\hline Jenis Kelamin & N & Persentase (\%) \\
\hline Laki-laki & 16 & 41 \\
Perempuan & 23 & 59 \\
\hline Total & 39 & 100 \\
\hline
\end{tabular}

Tabel 1 menunjukkan jenis kelamin responden sebagian besar berada pada jenis kelamin perempuan sebanyak 23 siswa (59\%).

Tabel 2. Distribusi frekuensi responden berdasarkan kelompok umur

\begin{tabular}{ccc}
\hline Umur (Tahun) & $\mathrm{N}$ & Persentase (\%) \\
\hline 10 & 3 & 7,7 \\
11 & 17 & 43,6 \\
12 & 16 & 41,0 \\
13 & 3 & 7,7 \\
\hline Total & 39 & 100 \\
\hline
\end{tabular}


Tabel 2 menunjukkan karakteristik umur responden sebagian besar berada pada usia 11 tahun sebanyak 17 siswa $(43,6 \%)$.

Tabel 3. Distribusi frekuensi responden berdasarkan tingkat pengetahuan tentang karies gigi

\begin{tabular}{ccc}
\hline Kriteria Pengetahuan & N & Persentase \\
\hline Baik & 37 & 94,9 \\
Cukup & 2 & 5,1 \\
Kurang & 0 & 0 \\
\hline Total & 39 & 100 \\
\hline
\end{tabular}

Tabel 3 menunjukkan pengetahuan tentang karies gigi sebagian besar berada pada kriteria baik sebanyak 37 siswa $(94,9 \%)$.

\begin{tabular}{ccc}
\multicolumn{3}{c}{ Tabel 4. Distribusi frekuensi responden berdasarkan Indeks DMF-T } \\
\hline Kategori DMF-T & $\mathrm{N}$ & Persentase \\
\hline Rendah & 25 & 64,1 \\
Sedang & 11 & 28,2 \\
Tinggi & 3 & 7,7 \\
\hline Total & 39 & 100
\end{tabular}

Tabel 4 menunjukkan kategori Indeks DMF-T sebagian besar berada pada kriteria rendah sebanyak 25 siswa $(64,1 \%)$.

Tabel 5. Hasil tabulasi silang antara Tingkat Pengetahuan Karies Gigi dengan Indeks DMF-T siswa kelas V SD Negeri Walitelon Utara Temanggung

\begin{tabular}{ccccccccc}
\hline Kriteria & \multicolumn{9}{c}{ Kategori DMF-T } & \multicolumn{3}{c}{ Total } \\
\cline { 2 - 9 } Pengetahuan & Rendah & $\%$ & Sedang & $\%$ & Tinggi & $\%$ & Jumlah & $\%$ \\
\hline Baik & 25 & 64,1 & 11 & 28,2 & 1 & 2,65 & 37 & 94,9 \\
Cukup & 0 & 0 & 0 & 0 & 2 &, 1 & 2 & 5,1 \\
Kurang & 0 & 0 & 0 & 0 & 0 & 0 & 0 & 0 \\
\hline Total & 25 & 64,1 & 11 & 28,2 & 3 & 7,7 & 39 & 100 \\
\hline
\end{tabular}

Tabel 5 menunjukkan tingkat pengetahuan tentang karies gigi terhadap Indeks DMF-T sebagian besar berada pada kriteria pengetahuan baik dan kategori Indeks DMF-T rendah dengan jumlah responden sebanyak 25 siswa $(64,1 \%)$.

Berdasarkan hasil penelitian hubungan antara tingkat pengetahuan tentang karies gigi dengan Indeks DMF-T pada siswa kelas V SD Negeri Walitelon Utara Temanggung dengan jumlah responden 39 siswa diketahui karakteristik responden sebagai berikut, berdasarkan jenis kelamin pada (tabel 1), responden laki-laki sebanyak 16 responden (41\%) dan responden perempuan sebanyak 23 responden (59\%), sehingga dapat diketahui jenis kelamin perempuan lebih banyak daripada jenis kelamin laki-laki. Hal ini disebabkan karena siswa kelas V SD Negeri Walitelon Utara Temanggung lebih banyak jenis kelamin perempuan daripada laki-laki. Hasil penelitian ini diperkuat penelitian sebelumnya di taman TK Tunas Wijaya, Denpasar Utara menyatakan bahwa sebagian besar responden berjenis kelamin perempuan $(51,9)$ dibandingkan responden berjenis kelamin laki-laki $(48,1) .^{2}$

Kriteria umur (tabel 2) menunjukkan responden berusia 10 tahun sebanyak 3 responden $(7,7 \%), 11$ tahun sebanyak 17 responden $(43,6 \%), 12$ tahun sebanyak 16 responden $(41 \%)$, dan 
12 tahun sebanyak 3 responden $(7,7 \%)$, sehingga dapat diketahui paling banyak responden penelitian di umur 11 tahun. Penelitian ini sesuai dengan penelitian sebelumnya di SDN Caturtunggal 4 Depok Sleman Yogyakarta menyatakan bahwa karakteristik berdasarkan kelompok umur sebagian besar yaitu 66 responden $(50,8 \%)$ adalah responden yang berusia 10-12 tahun. ${ }^{9}$

Kriteria tingkat pengetahuan tentang karies gigi pada (tabel 3) menunjukkan tingkat pengetahuan baik sebanyak 37 responden $(94,9 \%)$ dan tingkat pengetahuan cukup sebanyak 2 responden (5,1\%), sehingga dapat diketahui responden yang memiliki tingkat pengetahuan tentang karies gigi baik lebih banyak dibandingkan responden yang memiliki tingkat pengetahuan tentang karies gigi yang cukup. Hal ini disebabkan karena sosialisasi penyuluhan bisa didapatkan siswa melalui iklan di media elektronik maupun media cetak, sehingga siswa menjadi paham dan mengerti tentang cara mencegah terjadinya karies gigi. Penelitian ini didukung oleh penelitian di SD Muhammadiyah Sidokarto yang menyatakan bahwa sebagian besar responden mempunyai pengetahuan tentang karies gigi yang baik. ${ }^{10}$

Kategori Indeks DMF-T (tabel 4) diketahui Indeks DMF-T rendah sebanyak 25 responden (64,1\%), Indeks DMF-T sedang sebanyak 11 responden $(28,2 \%)$, dan Indeks DMF$\mathrm{T}$ tinggi sebanyak 3 responden $(7,7 \%)$, sehingga paling banyak responden memiliki Indeks DMF-T rendah. Hal ini menunjukkan bahwa karies gigi rendah disebabkan oleh pengetahuan siswa kelas V SD Negeri Walitelon Utara Temanggung tentang karies gigi yang baik sehingga siswa memiliki kebiasaan yang baik pula dalam menjaga kesehatan gigi dan mulut salah satunya menyikat gigi pagi setelah sarapan dan malam sebelum tidur. Penelitian ini sesuai dengan penelitian sebelumnya di SDN Danumaya Kabupaten Subang, bahwa hampir seluruh responden penelitian menderita karies gigi dengan kategori DMF-T rendah. ${ }^{11}$

DMF-T rata-rata siswa kelas V SD Negeri Walitelon Utara adalah 2,05\% sehingga masuk dalam kategori DMF-T rendah. Angka tersebut bila dibandingkan data Riskesdas 2013, status karies gigi di Indonesia dinilai dengan Indeks DMF-T mencapai 4,6\% pada usia dibawah 12 tahun, dengan demikian berarti status karies gigi siswa kelas V SD Negeri Walitelon Utara masih lebih rendah jika ditinjau secara nasional.

Hasil tabulasi silang tingkat pengetahuan tentang karies gigi dengan Indeks DMF-T (tabel 5) dapat diketahui kriteria pengetahuan baik dengan kategori DMF-T rendah sebanyak 25 responden (64,1\%), kategori DMF-T sedang sebanyak 11 responden $(28,2 \%)$, dan kategori DMF-T tinggi sebanyak 1 responden $(2,6 \%)$, sedangkan kriteria pengetahuan cukup dengan kategori DMF-T tinggi sebanyak 2 responden (5,1\%). Diketahui paling banyak responden memiliki kriteria tingkat pengetahuan tentang karies gigi baik dengan kategori DMF-T rendah. Penelitian ini sejalan dengan penelitian sebelumnya di SMP/MTS Pondok Pesantren Putri Ummul Mukminin, menyatakan bahwa semakin tinggi nilai pengetahuan, sikap, dan tindakan maka nilai Indeks DMF-T semakin rendah. ${ }^{12}$

Analisis data penelitian mengenai hubungan antara tingkat pengetahuan tentang karies gigi dengan Indeks DMF-T pada siswa kelas V SD Negeri Walitelon Utara Temanggung menggunakan uji korelasi Kendall's tau-b (tabel 6) diperoleh nilai $p=0,000(p<0,05)$, menunjukkan Ho ditolak dan Ha diterima yang menunjukkan ada hubungan antara tingkat pengetahuan tentang karies gigi dengan Indeks DMF-T siswa kelas V SD Negeri Walitelon Utara Temanggung. Hal ini disebabkan pengetahuan kesehatan gigi seseorang berhubungan dengan status karies giginya. Seseorang yang memiliki pengetahuan tinggi akan mudah mempengaruhi status karies giginya menjadi rendah apabila pengetahuan tersebut 
diterapkan dalam perilaku sehari-hari, di SD Negeri Walitelon Utara Temanggung perlu ditingkatkan pelayanan asuhan kesehatan gigi dan mulut melalui usaha kesehatan gigi dan mulut sekolah. Program yang diberikan berupa pelayanan asuhan dalam bentuk peningkatkan promosi, pencegahan, dan pengobatan sederhana yang ditujukan bagi siswa, dengan maksud agar siswa tersebut benar-benar bebas dari penyakit gigi dan mulut, apabila siswa memiliki gigi dan mulut yang sehat maka dapat membantu mereka berkonsentrasi dalam mengikuti pelajaran di kelas. Penelitian ini sesuai dengan penelitian sebelumnya di SD kelas IV dan V di Kecamatan Lueng Bata kota Banda Aceh menyatakan bahwa ada hubungan yang signifikan antara pengetahuan dengan status karies gigi. ${ }^{13}$

\section{Kesimpulan}

Kesimpulan dari penelitian ini adalah tingkat pengetahuan tentang karies gigi sebagian besar berada pada kriteria baik sebanyak 37 siswa (94,9\%), sedangkan kategori Indeks DMF$\mathrm{T}$ sebagian besar berada pada kriteria rendah sebanyak 25 siswa $(64,1 \%)$, sehingga ada hubungan yang signifikan antara tingkat pengetahuan karies gigi dengan indeks DMF-T pada siswa kelas V SD Negeri Walitelon Utara Temanggung.

\section{Daftar Pustaka}

I. Gayatri, RW \& Desi A. 20I4. Tingkat Pengetahuan Kesehatan Gigi Anak Sekolah Dasar Negeri Kauman 2 Malang.

2. Astuti, PAE., Mia AP., I Dewa MS. 2017. Hubungan tingkat konsumsi karbohidrat dengan kejadian karies pada anak taman kanak-kanak tunas wijaya, Desa Tonja, Kecamatan Denpasar Utara, I(2).

3. Lintang, JC., Henry P, \& Michael AL. 2015. Hubungan Tingkat Pengetahuan Pemeliharaan Siswa Sdn Tumaluntung Minahasa Utara. Jurnal E-Gigi (EG), 3, 567-572.

4. Sulendra, KT., Dwi WAF., Raditya N. 2013. Hubungan pH dan Viskositas Saliva terhadap Indeks DMF-T pada Siswa-siswi Sekolah Dasar Baletbaru I dan Baletbaru II Sukowono Jember (Relationship between Salivary pH and Viscosity to DMF-T Index of Pupils in Baletbaru I and Baletbaru II Elementary School). Fakultas Kedokteran Gigi Universitas Jember, 3-4.

5. Putri, HM., Herijulianti E., Nurjana N. 20I I. Ilmu Pencegahan Penyakit Jaringan Keras dan Jaringan Pendukung Gigi. Jakarta : Buku Kedokteran

6. Notoatmodjo, S. 2014. Metodologi Penelitian Kesehatan. Jakarta : Rineka Cipta.

7. Sugiyono. 2013. Statistika untuk Penelitian. Bandung: Alfabetah. h. 30-31, 68, 253, 352, 365.

8. Uyanto, SS. 2009. Pedoman Analisis Data Dengan SPSS. Yogyakarta: Graha Ilmu. h.I 46

9. Rosdewi, NN. 2015. Hubungan Tingkat Pengetahuan Siswa Tentang Karies Gigi Dan Kebiasaan Menggosok Gigi Dengan Kejadian Karies Gigi Siswa Kelas 3 dan Kelas 4 SDN Caturtunggal 4 Depok Sleman Yogyakarta Tahun 2013. Jurnal Medika Respati. Vol. X No.2 h. 59-67

I0. Astuti, NLP. 20II. Hubungan Tingkat Pengetahuan Orang Tua Tentang Karies Gigi Dengan Perilaku Pencegahan Karies Gigi Pada Anak Usia Sekolah Dasar (6-I2) Tahun di SD Muhammadiyah Sidokarto. Skripsi. Program Study Ilmu Keperawatan. Sekolah Tinggi Kesehatan A.Yani Yogyakarta . h.7I

I I. Dian, R., Sanusi A., dan Qoulsum A. 20I0. Hubungan Pengetahuan Dan Sikap Anak Sekolah Dengan Kejadian Karies Gigi Pada Anak Sekolah SDN Danumaya Wilayah Kerja Puskesmas Cibogo Kabupaten Subang Tahun 20I0. Bakti kencana Medika. Vol.3 No.7. h.337.

12. Arifah, AN. 2016. Hubungan Pengetahuan, Sikap Dan Tindakan Kesehatan Gigi Dan Mulut Terhadap Status Kesehatan Gigi Pelajar SMP/MTS Pondok Pesantren Putri Ummul Mukminin. Skripsi. Fakultas Kedokteran Gigi Universitas Hasanuddin. h.4I

13. Mardiah, A.,\& Andriani. (20I4). Faktor-Faktor yang Behubungan dengan Kejadian Karies terhadap Status Karies Gigi Murid Kelas IV dan V di Wilayah Kecamatan Lueng Bata kota Banda Aceh. Jurnal Kesehatan Ilmiah Nasuwakes. Vol 7. No I. h. 70-82 